\title{
Birth Control and Contraception: The Dilemma of Informed Consent
}

\author{
Kurt Kraetschmer* \\ Austria \\ *Corresponding author: Kurt Kraetschmer, MD, PhD, Hermanngasse 4, A-2700 WrNeustadt, Austria.
}

Submission: 㯺 October 30, 2017; Published: 㘹 August 20, 2018

\begin{abstract}
The paper analyses the most pertinent publications on contraceptive efficacy from the viewpoint of the principle of informed consent. It proves by way of an international comparison that some of the most prominent publications on this topic fall short of providing complete and comprehensive information. It concludes that U.S. women are not in a position to exercise their right of self decision due to a lack of information and disregard for the principle of nil nocere on the part of authors and publishers. The implications are heightened attention to the need of intensified counseling in the clinical practice.
\end{abstract}

Keywords: Contraception; Bioethics; Family planning; Reproductive medicine

\section{Introduction}

Despite a prognosticated falling world population growth rate, reproductive health care continues to be an issue of international urgency. U.S. researchers have added an additional aspect to sexual and reproductive health with the finding that "every $\$ 1$ spent on public funding for family planning saves taxpayers $\$ 3.74$ in pregnancy-related costs [1]. "Given that about sixty-two percent of women of reproductive age are currently using contraception [2], it can be estimated that this percentage would be considerably higher if women were informed more accurately about contraceptive methods. The following discussion aims at rectifying inaccurate data that are widely disseminated and at clarifying misunderstood notions of natural non-hormonal contraception.

\section{Discussion}

Whenever women inquire about the possibilites of contraception and birth control, they turn to the most influential authorities in this field to seek complete and comprehensible infomation. In doing so, they follow the stipulation of the Code of Ethics of the American Medical Association which states: "The patient's right of self-decision can be effectively exercised only if the patient possesses enough information to enable an intelligent choice [3]." Given such ethical requirement it is imperative that all those who act as provider of information on contraceptive options present the whole range of contraceptive possibilities to the consumer. Unfortunately, not all providers of information comply with this request. Among them, the Food and Drug Administration (FDA) is the most prominent, as it presented as early as 2013 a survey of FDA approved methods of birth control which, alas, is incomplete [4]. Although the FDA cites as its source the widelyknown authors of contraceptive technology [5], it does not render the entire findings of these authors in two important aspects. First, it does not indicate with the same precision the percentages of women who will not get pregnant; second, it leaves aside some of the contraceptive methods, which in contraceptive technology research appear as highly effective in case of perfect use.

According to contraceptive technology, the symptothermal method with a failure rate of 0.4 for perfect use appears as the most reliable of the fertility awareness-based methods, ie, those with no side effects or risks, and comes close to the 0.3 failure rate of combined pill and progestin-only pill. Other methods among those that have no side-effects and risks are Ovulation (3.0), TwoDay (4.0), and Standard Days (5.0); their efficacy is comparable to coitus interruptus (4.0) or diaphragm (6.0).

These data presented by sound scholarly research in contraceptive technology is frequently ignored by research and public health media. In many instances only one common failure rate for typical use is indicated whereas failure rates for perfect use are omitted. Thus, the U.S. Department of Health and Human Services [6] provides information on family planning and assigns collectively $24 \%$ ("number out of every 100 women who experienced an unintended pregnancy within the first year of typical use") to the so-called "fertility awareness-based methods." These are considered as the least effective, just slightly superior to the "spermicide method" (28\%), and no mention is made of the findings in research on contraceptive failure, where perfect use estimates for the most reliable of the fertility awareness-based methods are considered to be " 0.4 per 100 woman-years for the symptothermal method [7]," 3.2 for the Ovulation method, 3.5 for the Two Day method and 4.8 for the Standard Days method. 
The lack of accuracy and completeness found in public health media stands in contrast to European publications where each method is assigned its proper failure rate. Instead of collectively attributing failure rates to a group of methods, European scholars over the years have made efforts to assess each method individually [8]. As a result of these efforts the symptothermal method with a Pearl Index of 0.8 has emerged as the most reliable of the "natural family planning methods," followed by the basal temperature method (Pearl Index 1-3), cervical mucus (Pearl Index 15-32), and calendar after Knaus-Ogino (Pearl Index 15-40) [9]. The clear distinction among the various methods made by European research is rather an exception in U.S. publications where inaccurate failure rates are still being disseminated through various public health media and research publications.

As recently as 2015, the American Congress of Obstetricians and Gynecologists stated that natural family planning "is not as effective as other methods of birth control [10]." As can be seen from an international comparison it is misleading to speak collectively of natural family planning without distinguishing among the various methods; and it is incorrect to state that they are not as effective as other methods, because the efficacy of the symptothermal method in case of perfect use (0.4) is almost equal to oral contraceptives, ie, combined pill and progestin-only pill (0.3) [5]. Not surprisingly, the ACOG has denied its own 2015 statement in a more recent statement in which the fertility awareness methods are lauded for their advantages regarding cost and safety [11]

On the other hand, no rectification of an inaccurate ranking of fertility awareness-based methods has as yet been initiated by an institution as influential as the Centers for Disease Control (CDC), which still presents a ranking where the fertility awareness-based methods are not individually assessed but treated as a group belonging to the least effective methods [12].

Unexpectedly, even scholarly publications fail to honor the principle of informed consent. The widely-known National Health Statistics Report [2] speaks in an unspecific manner of "fertility awareness" and assesses the probability of pregnancy for typical use of all methods belonging to fertility awareness with one single rate of 25.3, and no figures are cited for perfect use of each one of these methods. Idiosyncratic failure rates are to be found also in well- known reference-books such as the MSD Manual [13]. Although this scholarly work explains correctly that the symptothermal method is the most precise in determining the days where abstinence is mandatory, it assigns a failure rate of $10 \%$, which obviously does not reflect the efficacy in case of perfect use established by international research as $0.3 \%$ [14].

\section{Conclusion}

As the above discussion shows, numerous highly influential agencies provide information on contraception, birth control, and family planing, but this information is either incomplete, inaccurate or outdated. The ensuing disadvantage for the consumer who expects to find information according to the principle of informed consent is ignorance of some of the safest (ie, no adverse events or interactions with other medications) natural methods and their noteworthy perfect use estimates.

Research publications and public health media should refrain, in the future, from disseminating information in a way that is incompatible with the principles of informed consent, nil nocere, and patient autonomy. These principles require that there be complete and comprehensive information for the patient, that priority be given to the least harmful method, and that each woman exercise her right of self-decision after having received information on all the available methods including side effects and risks.

\section{Implications}

If it is true that taxpayer money can be saved through family planning, it can be concluded that researchers and public health publishers should sense an ethical obligation in accordance with the principle of informed consent to strive for accuracy and completeness in information on contraceptive methods. In the clinical practice, the apparent burden of additional time commitment for counseling will be outweighed by the gains owing to the absence of any adverse events and interactions with other medications. Thus, it should be a primordial goal of reproductive health care that each woman be enabled to exercise her autonomy after having been informed comprehensively about all methods of contraception including their potential harm, so that a decision can be made also with respect to the least harmful methods, as stipulated by the bioethical principle of nil nocere (Table 1).

Table 1: Food and drug administration (FDA) approved methods of birth control.

\begin{tabular}{|c|c|c|c|}
\hline Methods & $\begin{array}{c}\text { *Number of Women Out } \\
\text { of 100 Who Will Not Get } \\
\text { Pregnant: "Perfect Use" }\end{array}$ & $\begin{array}{c}\text { *With Typical Use, Number } \\
\text { of Women Out of 100 Who } \\
\text { Will Not Get Pregnant }\end{array}$ & How to Use it \\
\hline $\begin{array}{c}\text { Sterilization Surgery for } \\
\text { Women }\end{array}$ & $>99 \%$ & $>99 \%$ & One-time procedure; nothing to do or remember. \\
\hline $\begin{array}{c}\text { Surgical Sterilization Im- } \\
\text { plant for Women }\end{array}$ & $>99 \%$ & $>99 \%$ & One-time procedure; nothing to do or remember. \\
\hline $\begin{array}{c}\text { Sterilization Surgery for } \\
\text { Men }\end{array}$ & $>99 \%$ & $\begin{array}{c}\text { One-time procedure; nothing to do or remember; con- } \\
\text { doms should be used for at least 3 months until stored } \\
\text { sperm are cleared from the reproductive tract. }\end{array}$ & \\
\hline
\end{tabular}




\begin{tabular}{|c|c|c|c|}
\hline Implantable Rod** & $>99 \%$ & $>99 \%$ & $\begin{array}{c}\text { Nothing to do or remember, lasts up to } 3 \text { years, inserted } \\
\text { by clinician. }\end{array}$ \\
\hline IUD** & $>99 \%$ & $>99 \%$ & $\begin{array}{l}\text { Nothing to do or remember, lasts 3-10 years, inserted } \\
\text { by clinician. }\end{array}$ \\
\hline Shot/Injection & $>99 \%$ & $94 \%$ & Need a shot every 3 months, prescription needed. \\
\hline $\begin{array}{l}\text { Oral Contraceptives } \\
\text { (Combined pill) “The Pill” }\end{array}$ & $>99 \%$ & $91 \%$ & Must swallow pill every day, prescription needed. \\
\hline $\begin{array}{l}\text { Oral Contraceptives } \\
\text { (Progestin-only) "The Pill" }\end{array}$ & $>99 \%$ & $91 \%$ & $\begin{array}{l}\text { Must swallow pill everyday. Must be taken at the same } \\
\text { time each day. Prescription needed. }\end{array}$ \\
\hline $\begin{array}{l}\text { Oral Contraceptives } \\
\text { Extended/Continuous Use: } \\
\text { "The Pill" }\end{array}$ & $>99 \%$ & $91 \%$ & Must swallow pill everyday. Prescription needed. \\
\hline Patch & $>99 \%$ & $91 \%$ & $\begin{array}{l}\text { Put on a new patch each week for three weeks ( } 21 \\
\text { total days). Don't put on patch during the fourth week. } \\
\text { Prescription needed. }\end{array}$ \\
\hline Vaginal Contraceptive Ring & $>99 \%$ & $91 \%$ & $\begin{array}{l}\text { Put the ring into the vagina yourself. Keep the ring } \\
\text { in vagina for three weeks and remove for one week. } \\
\text { Prescription needed. }\end{array}$ \\
\hline Male Condom & $98 \%$ & $82 \%$ & $\begin{array}{l}\text { Must use every time you have sex; requires partner's } \\
\text { cooperation. Except for abstinence, latex condoms are } \\
\text { the best protection against HIV/AIDS and other STIs. }\end{array}$ \\
\hline Diaphragm with Spermicide & $94 \%$ & $88 \%$ & Must use every time you have sex. \\
\hline Sponge with Spermicide & $80-91 \%$ & $76-88 \%$ & Must use every time you have sex. \\
\hline $\begin{array}{l}\text { Cervical Cap with Spermi- } \\
\text { cide }\end{array}$ & $74 \%$ & $60 \%$ & Must use every time you have sex. \\
\hline Female Condom & $95 \%$ & $79 \%$ & $\begin{array}{l}\text { Must use every time you have sex. May give some pro- } \\
\text { tection against STIs. }\end{array}$ \\
\hline Spermicide & $82 \%$ & $72 \%$ & $\begin{array}{c}\text { Must use every time you have sex. Associated with risk } \\
\text { of STI and HIV due to vaginal irritation with frequent } \\
\text { use. }\end{array}$ \\
\hline \multicolumn{4}{|c|}{ Emergency Contraception - If your primary method of birth control fails } \\
\hline $\begin{array}{l}\text { Emergency Contraceptives, } \\
\text { "Plan B," "Plan B One Step," } \\
\text { "Ella" }\end{array}$ & $85 \%$ & $\begin{array}{l}7 \text { out of } 8 \text { women would not } \\
\text { get pregnant after using Emer- } \\
\text { gency Contraceptives }\end{array}$ & $\begin{array}{l}\text { Must use within } 72-120 \text { hours of unprotected sex. It } \\
\text { is most effective taken as soon as possible after the } \\
\text { unprotected act. It should not be used as a regular } \\
\text { form of birth control. }\end{array}$ \\
\hline
\end{tabular}

*Effectiveness rates are listed for $\square$ perfect use" and $\square$ typical use."

**Implantable rod and IUD considered Long-Acting Reversible Contraceptives (LARC) and are highly recommended for young women who do not wish to become pregnant, but may want to have children later. Source: Contraceptive Technology $20^{\text {th }}, 2011$. 


\section{References}

1. Cleland K, Peipert J, Westhoff C, Spear S, Trussell J (2011) Family planning as a cost-saving preventive health service. NEJM 364(18): e37.

2. Jones J, Mosher W, Daniels K (2012) Current contraceptive use in the United States, 2006-2010, and changes in patterns of use since 1995 Natl Health Stat Report 60: 1-25.

3. Code of Medica Ethics (1992) Current opinions. American Medical Association, Illinois, Chicago, USA

4. (2016) US Food and Drug Administration.

5. Trussell J (2011) Contraceptive efficacy. In: Hatcher RA, Trussell J, Nelson AL, Cates W, Kowal D, et al. (Eds.), Contraceptive Technology, (12 edn), Ardent Media,. CT Failure, New York, USA.

6. (2016) US Department of Health.

7. Trussell J (2011) Contraceptive failure in the United States. Contraception 83(5): 397-404
8. Herrmann FP, Heil J, Gnoth C, Toledo E, Baur S, et al. (2007) The effectiveness of a fertility awareness-based method to avoid pregnancy in relation to a couple's sexual behaviour during the fertile time: a prospective longitudinal study. Human Reproduction 22(5): 1310-1319.

9. Gröger S, Grüne B (2000) Kontrazeption. In: Diedrich K (Ed.), Gynäkologie und Geburtshilfe. Springer, Berlin, Germany, pp. 60-87.

10. (2016) Birth control (Contraception): Resource overview. American Congress of Obstetricians and Gynecologists, USA.

11. (2017) Fertility Awareness-Based Methods of Family Planning. American Congress of Obstetricians and Gynecologists (ACOG), USA.

12. Centers for Disease Control and Prevention (CDC) (2016) US medical eligibility criteria for contraceptive use.

13. Beers MH, Berkow R (1999) MSD Manual. (17 ${ }^{\text {th }}$ edn), Merck \& Co Inc. Whitehouse Station, USA.

14. Freundl G, Sivin I, Batár I (2010) State-of-the-art of non-hormonal methods of contraception: IV. Natural family planning. Eur J Contracept Reprod Health Care 15(2): 113-123.
Creative Commons Attribution 4.0 International License

For possible submissions Click Here

\section{Submit Article}

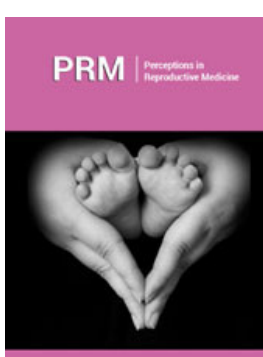

\section{Perceptions in Reproductive Medicine}

\section{Benefits of Publishing with us}

- High-level peer review and editorial services

- Freely accessible online immediately upon publication

- Authors retain the copyright to their work

- Licensing it under a Creative Commons license

- Visibility through different online platforms 